\title{
Glucocorticoid receptors in critically ill patients
}

\author{
Vassiliou AG ${ }^{1}$, Stamogiannos $\mathrm{G}^{2}$, Floros $\mathrm{G}^{2}$, Kotanidou $\mathrm{A}^{1,2}$ and Dimopoulou $\mathrm{I}^{2 *}$ \\ ${ }^{1}$ Department of Critical Care Medicine and Pulmonary Services, GP Livanos and M Simou Laboratories, Evangelismos Hospital, Athens Medical School, National \\ and Kapodistrian University of Athens, Athens, Greece \\ ${ }^{2}$ Department of Critical Care Medicine and Pulmonary Services, Evangelismos Hospital, Athens Medical School, National and Kapodistrian University of Athens, \\ Athens, Greece
}

\begin{abstract}
In critically ill patients, the hypothalamic-pituitary-adrenal axis is activated and as a consequence these patients exhibit increased serum cortisol concentrations. However, a number of patients have relatively low cortisol levels for the degree of illness severity. Glucocorticoid actions are facilitated by the glucocorticoid receptor whose dysfunction leads to glucocorticoid tissue resistance. Most clinical studies in critically ill adult patients have studied cortisol availability, and only a few have investigated glucocorticoid receptor levels and function.

In this review we will explore the conflicting results that have arisen from the clinical studies that aimed to elucidate the role of glucocorticoid receptor in glucocorticoid resistance. The study of receptor function and expression might aid in identifying the patients who will benefit from corticosteroid administration.
\end{abstract}

Glucocorticoids, the end-products of the hypothalamic-pituitaryadrenal (HPA) axis, have been used for over half a century in sepsis, however not all patients benefit from their use [1-4]. In critically ill patients, the HPA axis is activated causing increased serum cortisol concentrations [5-8], though a high number of septic [9] or non-septic [10] patients exist with low serum cortisol levels for the severity of their illness. This cellular corticosteroid availability and/or activity for the degree of illness severity resulting from dysfunction of the HPA axis is termed critical illness-related corticosteroid insufficiency (CIRCI) [11].

Cortisol signalling is mediated by a ubiquitous intracellular receptor protein, the glucocorticoid receptor (GCR). Two highly homologous isoforms of GCR result from alternative splicing of the primary transcript [12]. GCR- $\alpha$ is the classic functionally active receptor; after hormone binding it translocates from the cytosol to the nucleus where it exerts transcriptional activation or repression by directly binding to genes containing glucocorticoid responsive elements (GREs) [13]. The final outcome is the inhibition of the inflammatory response $[14,15]$. The function of GCR- $\beta$ is mostly unknown; it suppresses GCR- $\alpha$ activity and is unable to bind natural and synthetic ligands [16-18].

Current guidelines suggest the use of hydrocortisone in patients with septic shock resistant to vasoactive agents, however, not all patients respond appropriately pointing possibly towards glucocorticoid (GC) resistance [19]. GC resistance is the inability of glucocorticoids to exert their effects on target tissues [20]. It indicates a decrease in the sensitivity of immune cells to glucocorticoids, which under normal conditions terminate the inflammatory response [21]. So how tissues respond to cortisol is as important as the levels of the hormone itself. The extent of cortisol effect might be proportional to GCR expression, subtype, and affinity in a specific target cell [22]. For example, expression of GCR- $\beta$ is increased in tissues in inflammatory diseases and seems to be associated with decreased sensitivity to glucocorticoids [23].

It is uncertain whether GC resistance is a result of reduced GCR expression, decreased affinity of GCR for the ligand, reduced nuclear translocation, decreased DNA binding, or altered transcription factor interaction. Most clinical studies have investigated cortisol availability in critically ill patients, however the importance of GCR function has only been explored in a few clinical studies in adults yielding conflicting results. One group has described glucocorticoid resistance in a cohort of septic patients; their results showed lower GCR- $\alpha$ and increased GCR- $\beta$ expression levels in septic patients compared to healthy subjects, suggesting that steroid treatment might aggravate GC resistance in patients with high GCR- $\beta$ levels [24]. A transient increased expression of GCR- $\beta$ has been found in septic patients and furthermore, serum from these patients was able to induce GC resistance in vitro [25]. Another group reported reduced levels of GCR- $\alpha$ in sepsis [26], while reduced GCR protein levels has been reported in various organs during sepsis [27]. Also, in sepsis, decreased number of GCR- $\alpha$ and increased GCR- $\beta$ in heart and liver biopsies has been shown [28]. Evidence that GCR expression increased during septic shock, while GCR binding capacity decreased, proposed that it is the decreased GCR binding capacity that blocks the response to exogenous or endogenous glucocorticoids, rather than the number of receptors [29]. On the contrary, it has been shown that the GCR count and affinity in septic patients did not differ from normal controls, suggesting that glucocorticoids could still be effective in the hemodynamic compensatory phase of sepsis [30]. A recent study also showed increased GCR- $\alpha$ expression in the acute phase of sepsis, possibly implying no need for exogenous steroids at this phase [31]. In critical illness, only one study has demonstrated down-regulation of cortisol binding in ventilated patients [32]. Finally, a very recent study

${ }^{\star}$ Correspondence to: Ioanna Dimopoulou, 1st Department of Critical Care Medicine \& Pulmonary Services, "Evangelismos" Hospital, Ipsilantou 47-49, 10676, Athens, Greece, E-mail: idimo@otenet.gr

Key words: critically ill patients, glucocorticoid receptor, glucocorticoid resistance

Received: October 07, 2019; Accepted: October 28, 2019; Published: November 01,2019 
from our group demonstrated that critically ill, steroid-free patients have highly variable expression of both GCR isoforms in peripheral polymorphonuclear cells, and moreover, the levels of both receptors decrease during ICU stay [33].

\section{Conclusion}

The results of the aforementioned studies suggest that during critical illness GCR expression is independently regulated. This might explain the differential response of patients to exogenously administered steroids or endogenously secreted cortisol. Apart from GCR expression, future clinical studies should focus on the role of posttranslational modifications, the components of the GCR complex, and the efficiency of nuclear translocation of the GCR complex on tissue glucocorticoid sensitivity.

\section{References}

1. Annane D, Renault A, Brun-Buisson C, Megarbane B, Quenot JP, et al. (2018) Hydrocortisone plus Fludrocortisone for Adults with Septic Shock. N Engl J Med 378: 809-818. [Crossref]

2. Annane D, Sebille V, Charpentier C, Bollaert PE, François B, et al. (2002) Effect of treatment with low doses of hydrocortisone and fludrocortisone on mortality in patients with septic shock. JAMA 288: 862-871. [Crossref]

3. Sprung CL, Annane D, Keh D, Moreno R, Singer M, et al. (2008) Hydrocortisone therapy for patients with septic shock. $N$ Engl J Med 358: 111-124. [Crossref]

4. Venkatesh B, Finfer S, Cohen J, Rajbhandari D, Arabi Y, et al. (2018) Adjunctive Glucocorticoid Therapy in Patients with Septic Shock. N Engl J Med 378: 797-808. [Crossref]

5. Drucker D, McLaughlin J (1986) Adrenocortical dysfunction in acute medical illness. Crit care med 14: 789-791.

6. Drucker D, Shandling M (1985) Variable adrenocortical function in acute medical illness. Crit Care Med 13: 477-479.

7. Jurney TH, Cockrell JL, Lindberg JS, Lamiell JM, Wade CE (1987) Spectrum of serum cortisol response to ACTH in ICU patients. Correlation with degree of illness and mortality. Chest 92: 292-295.

8. Reincke M, Allolio B, Wurth G, Winkelmann W (1993) The hypothalamic-pituitaryadrenal axis in critical illness: response to dexamethasone and corticotropin-releasing hormone. J Clin Endocrinol Metab 77: 151-156.

9. Vassiliadi DA, Dimopoulou I, Tzanela M, Douka E, Livaditi O, et al. (2014) Longitudinal assessment of adrenal function in the early and prolonged phases of critical illness in septic patients: relations to cytokine levels and outcome. $J$ Clin Endocrinol Metab 99: 4471-4480.

10. Dimopoulou I, Stamoulis K, Ilias I, Tzanela M, Lyberopoulos P, et al. (2007) A prospective study on adrenal cortex responses and outcome prediction in acute critical illness: results from a large cohort of 203 mixed ICU patients. Intensive Care Med 33: 2116-2121.

11. Marik PE, Pastores SM, Annane D, Meduri GU, Sprung CL, et al. (2008) Recommendations for the diagnosis and management of corticosteroid insufficiency in critically ill adult patients: consensus statements from an international task force by the American College of Critical Care Medicine. Crit Care Med 36: 1937-1949.

12. Hollenberg SM, Weinberger C, Ong ES, Cerelli G, Oro A, et al. (1985) Primary structure and expression of a functional human glucocorticoid receptor cDNA. Nature 318: 635-641.

13. Kadmiel M, Cidlowski JA (2013) Glucocorticoid receptor signaling in health and disease. Trends Pharmacol Sci 34: 518-530.

14. Barnes PJ, Karin M (1997) Nuclear factor-kappaB: a pivotal transcription factor in chronic inflammatory diseases. $N$ Engl J Med 336: 1066-1071.
15. Gottlicher M, Heck S, Herrlich P (1998) Transcriptional crosstalk, the second mode of steroid hormone receptor action. J Mol Med 76: 480-489.

16. Bamberger CM, Bamberger AM, de Castro M, Chrousos GP (1995) Glucocorticoid receptor beta, a potential endogenous inhibitor of glucocorticoid action in humans. $J$ Clin Invest 95: 2435-2441.

17. Oakley RH, Sar M, Cidlowski JA (1196) The human glucocorticoid receptor beta isoform. Expression, biochemical properties, and putative function. J Biol Chem 271: 9550-9559.

18. Kino T, Su YA, Chrousos GP (2009) Human glucocorticoid receptor isoform beta: recent understanding of its potential implications in physiology and pathophysiology. Cell Mol Life Sci 66: 3435-3448.

19. Singer M, Deutschman CS, Seymour CW, Shankar-Hari M, Annane D, et al. (2016) The third international consensus definitions for sepsis and septic shock (Sepsis-3) JAMA 315: 801-810

20. Chrousos GP, Detera-Wadleigh SD, Karl M (1993) Syndromes of glucocorticoid resistance. Ann Intern Med 119: 1113-1124. [Crossref]

21. Marques AH, Silverman MN, Sternberg EM (2009) Glucocorticoid dysregulations and their clinical correlates. From receptors to therapeutics. Annals NY Acad Sci 1179: 1-18,

22. Bamberger CM, Schulte HM, Chrousos GP (1996) Molecular determinants of glucocorticoid receptor function and tissue sensitivity to glucocorticoids. Endocr Rev 17: $245-261$.

23. Colli LM, do Amaral FC, Torres N, de Castro M (2007) Interindividual glucocorticoid sensitivity in young healthy subjects: the role of glucocorticoid receptor alpha and beta isoforms ratio. Horm Metab Res 39: 425-429.

24. Ledderose C, Mohnle P, Limbeck E, Schutz S, Weis F, et al. (2012) Corticosteroid resistance in sepsis is influenced by microRNA-124--induced downregulation of glucocorticoid receptor-alpha. Crit Care Med 40: 2745-2753.

25. Guerrero J, Gatica HA, Rodríguez M, Estay R, Goecke IA (2013) Septic serum induces glucocorticoid resistance and modifies the expression of glucocorticoid isoforms receptors: a prospective cohort study and in vitro experimental assay. Crit Care 17: R107. [Crossref]

26. Molijn GJ, Koper JW, van Uffelen CJ, de Jong FH, Brinkmann AO, et al. (1995) Temperature-induced down-regulation of the glucocorticoid receptor in peripheral blood mononuclear leucocyte in patients with sepsis or septic shock. Clin Endocrinol (Oxf) 43: 197-203. [Crossref]

27. Dekelbab BH, Witchel SF, DeFranco DB (2007) TNF-alpha and glucocorticoid receptor interaction in L6 muscle cells: a cooperative downregulation of myosin heavy chain. Steroids 72: 705-712.

28. Abraham MN, Jimenez DM, Fernandes TD, et al. (2018) Cecal Ligation and Puncture Alters Glucocorticoid Receptor Expression. Crit Care Med 46: e797-797e804. [Crossref]

29. Bergquist M, Lindholm C, Strinnholm M, Hedenstierna G, Rylander C (2015) Impairment of neutrophilic glucocorticoid receptor function in patients treated with steroids for septic shock. Intensive Care Med Exp 3: 59. [Crossref]

30. Sigal GA, Maria DA, Katayama ML, Wajchenberg BL, Brentani MM (1993) Glucocorticoid receptors in mononuclear cells of patients with sepsis. Scand J Infect Dis 25: 245-248.

31. Vardas K, Ilia S, Sertedaki A, Charmandari E, et al. (2017) Increased glucocorticoid receptor expression in sepsis is related to heat shock proteins, cytokines, and cortisol and is associated with increased mortality. Intensive Care Med Exp 5: 10. [Crossref]

32. Siebig S, Meinel A, Rogler G, Klebl E, Wrede CE, et al. (2010) Decreased cytosolic glucocorticoid receptor levels in critically ill patients. Anaesth Intensive Care 38: 133140

33. Vassiliou AG, Floros G, Jahaj E, Stamogiannos G, Gennimata S, et al. (2019) Decreased glucocorticoid receptor expression during critical illness. Eur J Clin Invest 49: e13073. [Crossref]

Copyright: (C2019 Vassiliou AG. This is an open-access article distributed under the terms of the Creative Commons Attribution License, which permits unrestricted use, distribution, and reproduction in any medium, provided the original author and source are credited. 